\title{
Comparative Studies on Infectious Bursal Disease Virus Propagated in Chicken Eggs and Vero Cell Culture
}

\author{
Khodeir, M.H.*, El-Tarabeily, M.**Heba, H. El-Masry*** Shahira A. \\ Abdelwahab**and Mohamed Fawzy** \\ *Veterinary Serum and Vaccine Research Institute, Abassia, Cairo** \\ Virology Department,Faculty of Veterinary Medicine Suez Canal \\ University***Free Veterinarian.
}

\begin{abstract}
Ten bursal samples were pooled from the IBD infected birds in Damietta Governorate showing haemorrhagic and enlarged bursae. Bursal homogenates were used for ten-day-old embryonated specific pathogen free embryonated tests included VN and FAT tests revealed the incidence of IBDV antigen.

Propagation of the obtained isolate in ECE and Vero cells for 10 passages revealed gradual increase in the virus titer up to 8 $\log 10 \mathrm{EID}_{50} / \mathrm{ml}$ and $7.5 \mathrm{TCID}_{50} / \mathrm{ml}$ respectively.

Original, egg adapted, cell culture adapted and bursavac samples were used for viral RNA extraction by using reagent---- (Trizol). RT-PCR was performed for samples using V1 and V2 pair of primers of hypervariable region of VP2 gene to confirm the presence of IBDV in cell culture. The results of Viral RNA extracted from all samples is generation of a targeted amplicon of $472 \mathrm{bp}$ confirming that there were no differences between any of them.
\end{abstract}

\section{Introduction}

Infectious bursal disease is a highly contagious disease of young chickens (3-6 weeks of age) caused by IBDV, characterized by immunosuppression. The disease is characterized by damage of lymphoid cells in the bursa of fabricius.

Chicks infected less than one-week of age suffer from severe and permanent B-cell immunosuppression (Van- den Berg et al., 2000). The cause of the disease is a double stranded ; bisegmented, RNA virus is belongs to Birnavirideae family (Jackwood et al, 2008). The virus have two serotypes. serotype 1 strains are Pathogenic but serotype 2 strains are non-pathogenic (Mcferran et al, 1980).

Regarding virus propagation in ECE, Yamaguchi et al. (1996) reported that isolates of IBDV were successfully adapted on chicken egg embryos and no pathogenic lesions were found after inoculation to the natural host (11 days old chicks). 
Lazarus et al., (2008) found that the titer of IBD virus increased gradually from passage number 6 to 13 and then it remained consistent throughout the experiment.

Kibenge et al. (1988) reported that latent period of IBDV for Vero cells took about 18 hours and longer multiplication cycles took two days have been reported. They found that in Vero is high yields and extensive maturation phase of the virus than in CEF cultures. El-Ebiary et al. (1997) replicated an attenuated strain of IBDV in BHKcells, vero cells and CEF and made comparison with 6 attenuated and live vaccines to be used as cell culture vaccines. The CPE of IBDV grown in BHK and CEF was the same, it was distinct after 9 passages at 2 days post inoculation with the peak titres of $10^{5}$ TCID50/ $0.1 \mathrm{ml}$ at $60 \mathrm{hr}$.

The present study was designed to investigate the virus affection by its propagation in embryonated chicken eggs and Vero cell culture.

\section{Material and methods \\ Samples:}

Ten bursae were collected aseptically from each of 10 broilers chicken flocks suspected to be naturally infected with IBDV in Damietta Governorate .These birds were owned to farmers represented different breeds (Local and Sasso). The age of the birds in these flocks ranged from 20-30 days. Diseased birds were suffered from lowered feed intake, stunted growth, watery diarrhea and ruffled feathers. The morbidity rate was $20 \%$ while the mortality rate was ranged between 4 and $8 \%$. These flocks were not vaccinated against IBDV infection. Dead birds showed enlarged, hemorrhagic or atrophied bursae, hemorrhagic batches on the breast and thigh muscles and severe nephrosis.

The collected bursae of each chicken flock of each were pooled according to Lukert et al. (2003) and homogenized using tissue homogenizer with addition of $10 \%$ antibiotic solution (Penicillin Gsodium $100 \quad \mathrm{IU} / \mathrm{ml}$ and Streptomycin Sulfate $100 \mathrm{mg} / \mathrm{ml}$ ) and then centrifuged at 2000rpm for 10 minutes at cool centrifuge. The supernatant fluid was obtained and preserved at $-70^{\circ} \mathrm{C}$ till using for trials of virus isolation.

\section{Refernce IBD virus:}

Bursa Vac IBD vaccine was supplied by Intervet-Schering Plough Animal Health and considered as a reference control in the included studies.

Specific pathogen free
ebmryonated chicken eggs (SPF):

SPF embryonated chicken eggs (911 day-old) were kindely supplied by Veterinary Serum and Vaccine Research Institute (VSVRI), Abassia, Cairo.

\section{Cell culture:}

African green monkey kidney (Vero) cell monolayer was supplied by VSVRI and used for virus isolation; virus titration; 
demonstration of the induced CPE and FAT.

Anti-IBD serum and conjugated serum with fluorescin isothiocyante:

Anti-IBD serum and serum conjugated with fluorescin isothiocyanate (Abd El-Wanies and Khodeir, 2004) were supplied kindely by VSVRI and used for identification of the obtained virus isolates using virus neutralization test and direct fluorescent antibody technique.

\section{Used primers:}

Table (1): Details of the 2 primer sets used for PCR

\begin{tabular}{|c|c|c|c|}
\hline $\begin{array}{c}\text { Sr. } \\
\text { No }\end{array}$ & $\begin{array}{c}\text { Primer } \\
\text { Name }\end{array}$ & Primer sequence & \multirow{2}{*}{ Reference } \\
\hline 1 & V1 (F) & 5'-CCA GAG TCT ACA CCA TAA-'3 & Bayliss et al \\
\cline { 1 - 2 } 2 & V2 (R) & 5'-CCT GTT GCC ACT CTT TCG TA'3 & 1990. \\
\hline
\end{tabular}

Isolation and propagation of IBDV:

\section{In SPF eggs:}

Ten-day-old embryonated SPF eggs were inoculated with $0.1 \mathrm{ml} / \mathrm{egg}$ of bursal tissue homogenate supernatant fluid by (CAM) route and put in incubation at $37^{\circ} \mathrm{C}$ according to Rosenberger et al. (2008) through 10 successive passages. Each sample was inoculated into 15 eggs and inoculated eggs with normal saline and bursaVac virus were included as controls. Eggs were candled daily for one week and mortality was recorded. At the $7^{\text {th }}$ day postinoculation (PI), the eggs were chilled at $4^{\circ} \mathrm{C}$ for 24 hours. Embryos were examined for gross IBD lesions. Characteristic embryo lesions of classic IBDV include early mortality (3-5 days post inoculation), liver necrosis, hemorrhage, a pale heart, edematous extension of the abdomen, and a pale spleen.
Characteristic lesions induced by variant IBDV strains include creamcolored, edematous embryos with bile stasis of the liver, liver necrosis, splenomegaly and limited mortality.

\section{In vero cell line:}

Culture flasks of vero cells having confluent monolayers were washed with phosphate buffer saline and 1 $\mathrm{ml}$ of the suspension of bursa was layered over the monolayer then put in incubation at $37^{0} \mathrm{C}$ for 1 hour with making good shaking to ensure viral adsorption. Bursavac live vaccine was used as reference control. Normal non-infected cell culture controls were included.

The infected flasks were washed twice with PBS then added $10 \mathrm{ml}$ of maintenance medium and incubated at $37^{\circ} \mathrm{C}$ and making examination every day by using the inverted microscope for detection of induced CPE. After the appearance of specific CPE, the cells were freezed until next 
passage.We repeated the same procedure for 10 serial passages.

\section{Virus titration:}

Each viral passage in eggs and cell culture was titrated in the corresponding host using the according to Florence et al (1992) using 10 fold dilution and we calculated the virus titer according to Reed and Muench (1938).

Virus neutralization:

It was carried out according to Gelb (2010) using specific antiserum in vero cell culture as a confirmatory test to ensure that the obtained isolates were IBDV

\section{Fluorescent antibody technique:}

It was carried out according to Allen et al. (1984) where cell lines of monkey kidney (Vero) were grown in 96-well, flat-bottom microtiter plate. Cell cultures were inoculated with IBDV and incubated at $37^{\circ} \mathrm{C}$ in an atmosphere of $\mathrm{CO} 2$ is $5 \%$ and air is $95 \%$ until ready to stain with specific conjugated hyperimmune serum. The stained cells were examined under a fluorescent microscope .

\section{Demonstration of IBDV cytopathic effect:}

Vero cells were grown in Leighton's tubes containing cover slips. Some of these tubes were infected with IBDV while other tubes were kept without infection as control. After the appearance of clear CPE, infected and normal cell cultures were stained with Haematoxylin and Eosin according to Carleton (1967). Other infected cell culture slips were left without staining for the application of FAT.

\section{Viral RNA Extraction:}

RNA was extracted directly from infected tissue culture samples, total RNA was extracted by using reagent (TRIZOL). Briefly, suspended in $1000 \mu$ of TRIZOL and $200 \mu \mathrm{l}$ of chloroform, vortexed vigorously, and spun at $16,000 \mathrm{xg}$ for 15 minutes at $4 \mathrm{C}$. The RNA was collected in the aqueous phase and precipitated with $600 \mu \mathrm{l}$ of isopropanol and spun at $16,000 \mathrm{xg}$ for 15 minutes at $4 \mathrm{C}$. The resultant total RNA pellet was washed 3 times with $70 \%$ ethanol. The total RNA was finally dissolved in $15 \mu \mathrm{l}$ of water (RNase-free) and was kept at $-30 \mathrm{C}$ until use.

\section{Reverse Transcription- Polymerase Chain Reaction (RT- PCR);}

RT-PCR targeting the VP2 variable region of IBDV was performed as follows. $5 \mu$ of RNA soln. was denatured at $97^{\circ} \mathrm{C}$ for $5 \mathrm{~min}$, after mixing with $1.5 \mu \mathrm{l}$ of dimethylsulfoxide, and immediately transferred to ice. Next, $2.5 \mu \mathrm{l}$ of $5 \mathrm{x}$ RT buffer $.2 .5 \mu \mathrm{l}$ of $2 \mathrm{mM}$ of each dNTP (Takara Bio, Shiga, Japan); $0.5 \mu \mathrm{l}$ of $25 \mu \mathrm{M}$ of a forward primer V1 5'-CCA GAG TCT ACA CCA TAA-' 3 and a reverse primer V2 5'CCT GTT GCC ACT CTT TCG TA-'3, which were designed in our laboratory . (Location from 739 to $1210 \mathrm{bp}$ of 52/70 strain, reported by Bayliss et al. (1990); $20 \mathrm{U}$ of RNase inhibitor (Toyobo); and $25 \mathrm{U}$ of ReverTra Ace (Toyobo) were 
mixed with denatured RNA in total mixture volume of $12.5 \mu \mathrm{l}$. The mixture was put in incubation for 30 minutes at $42^{\circ} \mathrm{C}$ for complementary DNA (cDNA) synthesis. The reaction was stopped at $94 \mathrm{C}$ for 5 minutes and transferred to ice. The resulting cDNA was further incubated with $1.25 \mathrm{U}$ of ExTaq (Takara Bio), $4 \mu 1$ of $10 \mathrm{mM}$ of each dNTP, $2 \mu \mathrm{l}$ of 25 $\mu \mathrm{M}$ of $\mathrm{V} 1$ and V2 primers, and distilled water to a final volume of $50 \mu \mathrm{l}$. PCR was run as the following cycles: initial denaturation: $94^{\circ} \mathrm{C}$ for 3 minutes, denaturation $94^{\circ} \mathrm{C}$ for 30 second , $57^{\circ} \mathrm{C}$ for 30 second, $72^{\circ} \mathrm{C}$ for 40 second of totals 35 cycles, and final extension for 5 minutes at $72^{\circ} \mathrm{C}$. The amplified PCR products were subjected to electrophoresis, stained by using stain called ethidium bromide, and see it by an ultraviolet transilluminator. The expected RTPCR product size was 472 bp. Total RNA directly extracted from a DV86-infected bursa was used as a positive control. Total RNA extracted from an uninfected bursa or distilled water instead of the RNA sample was used as a negative control.

\section{Results and discussion}

The experimental work showed that sampled birds were suffered from lowered feed intake, stunted growth, watery diarrhea and ruffled feathers. The morbidity rate was ranged between 15 and $20 \%$ while the mortality rate was ranged between 5 and $8 \%$. Although the flocks did not vaccinated against IBDV infection, dead birds showed enlarged, hemorrhagic or atrophied bursae, hemorrhagic batches on the breast and thigh muscles and severe nephrosis. These findings suggested that the causative agent is IBDV similar findings were recorded by Van Den Berg et al (2000); Muller et al (2003); and Eterradossi et al (2008).

Virus isolation on embryonated chicken eggs showed that specific embryo deaths were recorded by the 2 days post egg inoculation through the dropped chorioalantoic membrane showing changes happened to dead embryos were varied where in some cases there was hemorrhage and sever congestion in the toes and in the feather tracts of the skin while some showed little congestion on the toes and head as shown in figure (1B). In this respect Hitchner et al (1970) and Kosters et al (1971) used embryonated chicken eggs to isolate and propagate IBDV. It was noticed that the titer of virus was increased by serial passage in SPF eggs as tabulated in table (2) according to the virus adaptation reaching $8 \log 10 \mathrm{EID}_{50} / \mathrm{ml}$ by the tenth passage in similar manner to what reported by El-Ebiary et al. (1997). Virus isolation on Vero cell culture revealed increasing virus titer by serial passage (table-3) confirming that the cellular changes are due to 
virus infection. Pronounced $\mathrm{CPE}$ was detectable by the $2^{\text {nd }}$ day post infection reaching its maximum level by the $3^{\text {rd }}$ day. As shown in figure (3) the induced CPE was characterized by cell rounding; cell clumping and detachment of the cell sheet. These results come to be confirmed by those of Kibenge et al. (1988) who mentioned that the variant IBDV is different in Vero cells and other viruses by appearing rising cell associated virus titers and extracellular through three days of noticeable time. Reddy et al. (1989) isolated IBDV on BGM-70 and vero. The virus could replicate in healthy dividing cells without the need of adapting by passages; Dash et al. (1991) stated that Vero cell lines were found good for replication of IBDV; Tsai et al. (1992) showed that the CPE of IBDV is rounding, granulation of cell and finally detachment of the cells from surface within five days post inoculation ; Tao et al. (1995) successfully adapted to Vero cell line about 7 field isolates of IBD virus from 6 governorates in China, and the CPE was observed in all the isolates after passage on Vero cells for four generations ;Silva et al. (2004) noticed that CPE was showed gradual detachment of monolayers and marked granulation of cell cytoplasm.

Identification of the obtained isolates was carried out through the application of virus neutralization test (VNT) using specific antiIBDV in both of SPF embryonated chicken eggs and Vero cells. Inoculation of virus-serum mixture in eggs did not show any deaths or abnormalities and inoculated cells did not show any cellular changes indicating that the tested virus is IBDV. Jackwood et al. (1987) stated that VNT is only serologic test to differentiate the serotypes 1 and serotype 2 of IBDV and also to differentiate the antibodies of different subtypes of the virus , recorded about 6 different antigenic subtypes of the virus serotype 1 in vitro by virus neutralization test and noticed that the titers of VNT is reflect the protection of chickens to IBDV. Hassan et al. (1996) found that the monoclonal antibody was less sensitive than the polyclonal antigen capture for finding of IBDV antigen .

In addition, application of fluorescent antibody technique on bursal homogenates and infected Vero cell showed specific bright apple green reaction confined mainly in the cell cytoplasm confirming that the obtained isolates are IBDV (figure4\&5). Rosales et al. (1989) succeeded to make isolation of 2 isolates U-28 \& 3212 of IBDV by using SPF. They could not noticed CPE after four days in CEF cultures, and after 4 passages, the virus was observed by immune-fluoresence. Also $\boldsymbol{A b \boldsymbol { d }} \boldsymbol{E \boldsymbol { l }}$ Wanies and Khodeir (2004) prepared and used anti-IBDV serum conjugated with flourescine isothyocyante for detection of the virus antigen. 
Detection of IBDV in infected fluids by RT-PCR could aid to know nucleotide sequence variation of IBDV. In the present study, 10 bursal samples were collected from Damietta governorate from chickens with clinical signs and lesions that were characteristic of gumboro infection and analyzed for presence and determination the genotype of IBDv. These samples were identified positive for IBDvs on the basis the partial amplification of VP2 by RT-PCR .

RT-PCR has been used many times for confirming the presence of IBDV in cell culture (Silva et al., 2004). 7 amino acid sequences of the major structural VP2 protein were obtained from RT-PCR positive samples ( 2 from original bursal homogenate; 2 from egg adapted virus; 2 from cell culture adapted virus and one bursaVac). It was found that there were no changes in the molecular characters of IBDV by egg or cell culture passage figure (6). In this respect Hassan and Saif (1996) showed that egg or cell culture passage of IBDV did not affect the antigenicity of the virus. In addition, these findings reflect the fact that cell culture IBDV vaccines are potent vaccines able to protect chickens against the virus infection as stated by Aliev et al (1991) and El-Ebiary et al (1997).

Table (2): IBDV isolation in embryonated SPF eggs

\begin{tabular}{|c|c|c|c|c|c|c|c|c|}
\hline \multirow{2}{*}{$\begin{array}{l}\text { Passage } \\
\text { number }\end{array}$} & \multicolumn{7}{|c|}{ Number of embryo deaths/days post inoculation(DPI) } & \multirow{2}{*}{$\begin{array}{c}\text { Virus titer } \\
\log 10 \mathrm{EID}_{50} / \mathrm{ml}\end{array}$} \\
\hline & 1DPI & 2DPI & 3DPI & 4DPI & 5DPI & 6DPI & 7DPI & \\
\hline 1 & $0 / 15$ & $0 / 15$ & $3 / 15$ & $2 / 12$ & $2 / 10$ & $0 / 8$ & $0 / 8$ & 2 \\
\hline 2 & $0 / 15$ & $0 / 15$ & $2 / 15$ & $2 / 13$ & $1 / 11$ & $0 / 10$ & $0 / 10$ & 3 \\
\hline 3 & $3 / 15$ & $1 / 12$ & $1 / 11$ & $2 / 10$ & $1 / 8$ & $0 / 7$ & $0 / 7$ & 3 \\
\hline 4 & $1 / 15$ & $0 / 14$ & $4 / 14$ & $2 / 10$ & $1 / 8$ & $0 / 7$ & $0 / 7$ & 4.5 \\
\hline 5 & $0 / 15$ & $0 / 15$ & $5 / 15$ & $3 / 10$ & $2 / 7$ & $1 / 5$ & $0 / 4$ & 5 \\
\hline 6 & $2 / 15$ & $0 / 13$ & $4 / 13$ & $2 / 9$ & $1 / 7$ & $0 / 6$ & $0 / 6$ & 6 \\
\hline 7 & $3 / 15$ & $0 / 12$ & $3 / 12$ & $3 / 9$ & $2 / 6$ & $0 / 4$ & $0 / 4$ & 7 \\
\hline 8 & $0 / 15$ & $2 / 15$ & $4 / 13$ & $5 / 9$ & $1 / 4$ & $0 / 3$ & $0 / 3$ & 6.5 \\
\hline 9 & $1 / 15$ & $0 / 14$ & $3 / 14$ & $3 / 11$ & $2 / 8$ & $0 / 6$ & $0 / 6$ & 7 \\
\hline 10 & $0 / 15$ & $0 / 15$ & $1 / 15$ & $4 / 14$ & $2 / 10$ & $1 / 8$ & $0 / 7$ & 8 \\
\hline Control & 0 & 0 & 0 & 0 & 0 & 0 & 0 & 0 \\
\hline
\end{tabular}

Table (3): Isolation of IBDV in Vero cell culture

\begin{tabular}{|c|c|c|c|}
\hline Passage number & $\begin{array}{c}\text { Onset of CPE } \\
\left(\text { DPI }^{*}\right)\end{array}$ & $\begin{array}{c}\text { Virus harvestation } \\
(\mathrm{DPI})\end{array}$ & $\begin{array}{c}\text { Virus titer } \\
\left(\log 10 \mathrm{TCID}_{50} / \mathrm{ml}\right)\end{array}$ \\
\hline 1 & 4 & 7 & 1.5 \\
\hline 2 & 4 & 6 & 5 \\
\hline 3 & 3 & 5 & 5.5 \\
\hline 4 & 3 & 5 & 6 \\
\hline 5 & 2 & 5 & 6.5 \\
\hline 6 & 2 & 4 & 7 \\
\hline 7 & 1 & 4 & \\
\hline 8 & 1 & 3 & \\
\hline
\end{tabular}




\begin{tabular}{|c|c|c|c|}
\hline \hline \multicolumn{3}{|c|}{} \\
\hline 9 & 1 & 3 & 7.5 \\
\hline 10 & 1 & 3 & 7.5 \\
\hline
\end{tabular}
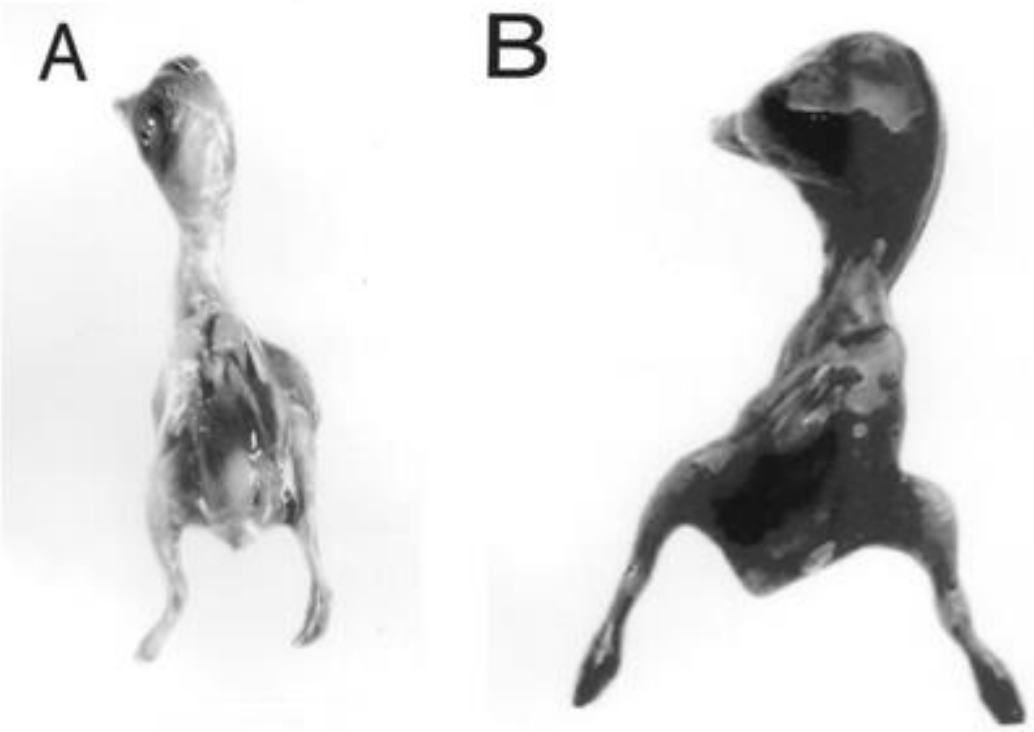

Fig (1A): Normal chicken embryo Fig (1B): IBD infected chicken embryo
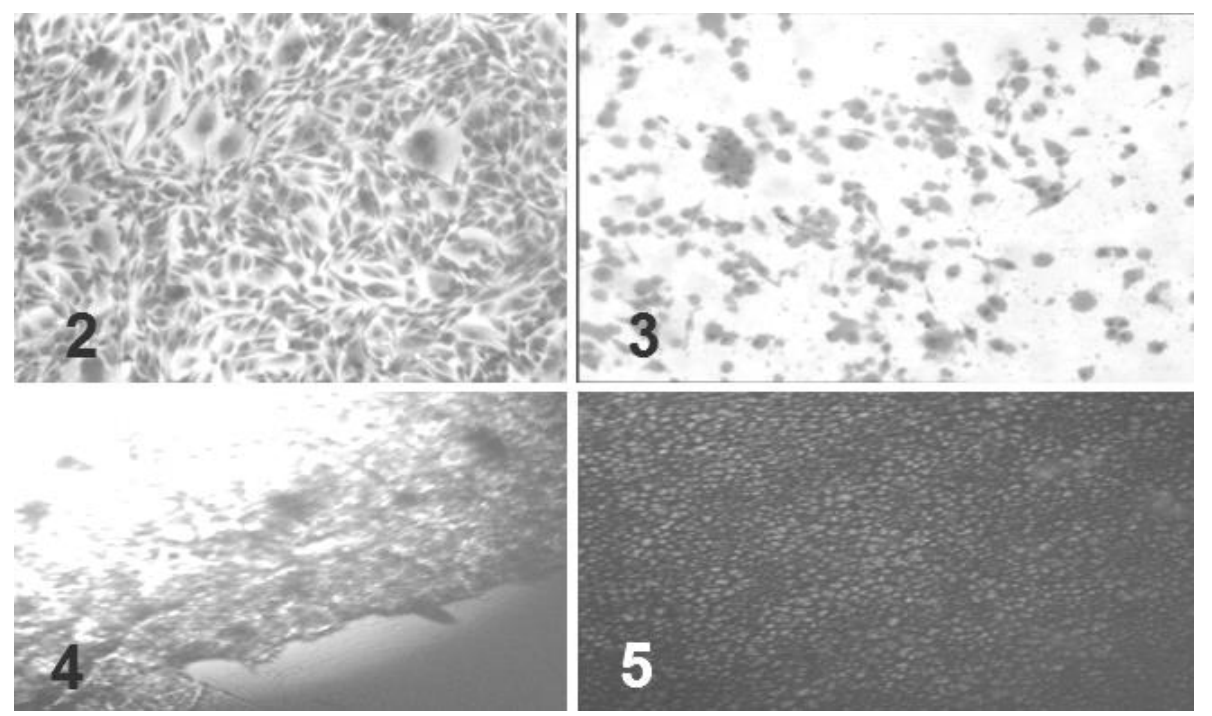

Fig (2): Normal Vero cell culture (H\&E, 100xs)

Fig (3): Vero cell culture infected with IBDV showing cell rounding, clumbing and cell detachment (H\&E, 100xs)

Fig (4): Positive FAT showing apple green reaction as carried out on bursa homogenate.

Fig (5): Positive FAT showing apple green reaction in the cytoplasm of Vero cells with isolated IBDV (100x) 


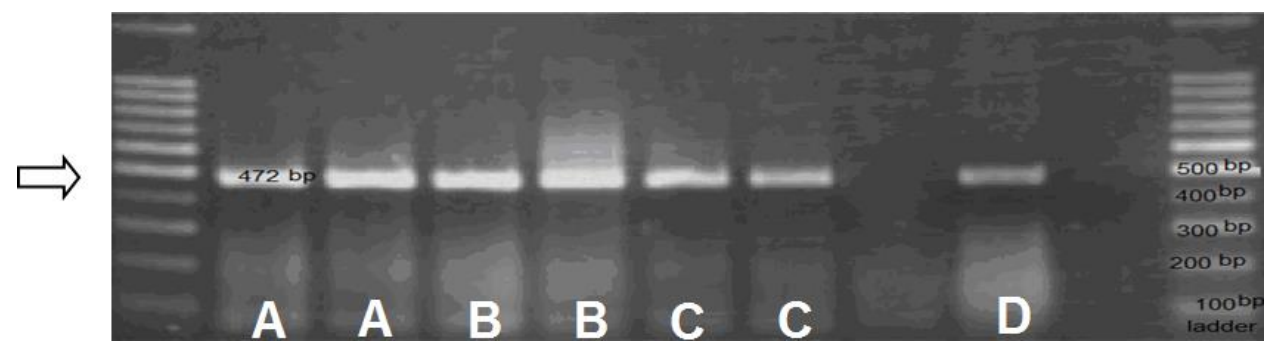

Fig (6): Agarose gel electrophoresis of 472 bp PCR products by RT-PCR. $\mathrm{A}=\mathrm{IBDV}$ in original bursal homogenate $\mathrm{B}=$ egg adapted IBDV $\mathrm{C}=$ cell culture adapted IBDV $\quad \mathrm{D}=$ Bursavac

References

Abd El-Wanis, N.A. and Khodeir, M.H. (2004): Conjugation of immunoglobulins prepared against infectious bursal disease virus in different hosts with fluorescine isothiocyanate Egyp. J. Agric. Res. 2004, Vol. 82 (4): 1881-1889.

Aliev, A.S.; Omarov, I.D.; Mirnyi, V.P. and Aleiv, T.S. (1991): Propagation of the virus of infectious bursal disease of poultry and interferon production Veterinariya (Moskva). 12: 21-23. (Vet. Bull. 62: 2520).

Allan, W. H., J. T. Faragher and G. A. Cullen (1972): Immunosuppression by the infectious bursal agent in chickens immunised against Newcastle disease.Vet Rec 90:511-2.

Allen, G.M.; Mcnulty, M.S.; Conner, T.J.; Mccracken, R.M. and Mcferran, J.B.(1984): Rapid diagnosis of infectious disease infection by immunofluorescence on clinical material .Avian Pathol. 13: 419-427.

Bayliss, C. D., U. Spies, K. Shaw, R. W. Peters, A. Papageorgiou, H.
Muller and M. E. Boursnell.(1990): A comparison of the sequences of segment $\mathrm{A}$ of four infectious bursal disease virus strains and identification of a variable region in VP2. J Gen Virol 71 (6):1303-12.

Carleton, H. M. (1967): Histological technique 4th Ed. New York, London and Toronto, Oxford university.Press.

Dash, B.B.; Verma, K.C. and Kataria, J.M. et al. (1991): Comparison of some serological tests for detection of IBD virus infection in chicken Indian J. Poult. Sci.26: 160-165.

EL-Ebiary, E.A.; Madhy, S.S. and Khodeir, M.H. (1997): Trials of using cell cultures for evaluation of IBDV vaccines in Egypt Assiut Veterinary Medical Journal.36:105123.

Eterradossi, N. and Saif, Y. M. (2008): Infectious Bursal Disease In Y. M. Saif, A. M. Fadly, J. R. Glisson, L. R. McDougald, L. K. Nolan, and D. E. Swayne . Diseases of Poultry, $12^{\text {th }}$ ed Blackwell 
Publishing Professional: Ames, IA, 185-208.

Florence, G. Burleson; Thomas,M. Chambers and Danny, L.Wiedbrauk (1992): Virology, A Laboratory Manual .Academic press, New York.

Gelb, J.Jr.; Preskenis, L.A.; Ladman, B.S.; Spackman, E. and Pope, C.R. (2010): Shore-bird origin Low Pathogenicity H7 Avian influenza virus differs in

its replication in ducks. Proc. $147^{\text {th }}$ American Vet. Med. Assn./American Assn. Avian Pathol. Ann. Mtg.Atlanta Georgia, Aug. 2-4.

Hassan, M. K. and Y. M. Saif (1996): Influence of the host system on the pathogenicity, immunogenicity, and antigenicity of infectious bursal disease virus. Avian Dis 40:553-61.

Hassan, M. K., M. Q. al-Natour, L. A. Ward and Y. M. Saif (1996): Pathogenicity, attenuation, and immunogenicity of infectious bursal disease virus. Avian Dis 40:567-71.

Hitchner, S. B. (1970): Infectivity of infectious bursal disease virus for embryonating eggs. Poult Sci 49:511-16.

Jackwood, D. H., Y. M. Saif and J. H. Hughes (1987): Replication of infectious bursal disease virus in continuous cell lines.Avian Dis 31:370-5.

Jackwood, D. H., Y. M. Saif and J. H. Hughes (1987): Replication of infectious bursal disease virus in continuous cell lines.Avian Dis 31:370-5.
Jackwood D. J., Sreedevi B., LeFever L. J., Sommer -Wagner S. E., (2008): Studies on naturally occurring infectious bursal disease viruses suggest that a single amino acid substitution at position 253 in VP2 increases pathogenicity Virology, vol.377, no.1, pp.110116

Kibenge, F. S., A. S. Dhillon and R. G. Russell (1988): Growth of serotypes I and II and variant strains of infectious bursal disease virus in Vero cells Avian Dis 32(2):298303.

Kosters, J. and Paulsen, J. (1971): Multiplication of the causal agent of infectious bursitis of fowls (Gumboro disease) in chick embryo kidney cultures Zentrable.Vet. Med. 18: 366-372.

Lazarus, D., M. Pasmanik-Chor, B. Gutter, G. Gallili, M. Barbakov, S. Krispel, J. Pitcovski, (2008) : Attenuation of very virulent infectious bursal disease virus and comparison of full sequences of virulent and attenuated strains. Avian Path., 2008, 3: 151159.

Mcferran, J. B., M.S.McNulty, E.R Mckillop, T.J.Conner, R.M. McCracken, D.S. Collins, and G.M. Allan (1980): Isolation and serologic studies with infectious bursal disease virus from fowl, turkey and duck: Demonstartion of a second serotype .Avian Pathol 9:395-404

Muller, H., M. R. Islam and R. Raue (2003): Research on infectious bursal disease--the past, 
the present and the futureVet Microbiol 97:153-65.

Muller, H., H. Lange and $H$. Becht (1986): Formation, characterization and interfering capacity of a small plaque mutant and of incomplete virus particles of infectious bursal disease virus .Virus Res 4:297-309.

Reed, L.J. and Muench, H. (1938): A simple method for estimating 50 percent end points.Am.J.Hyg. 27: 493-497.

Reddy, S.K. and Silim, A. (1989): Isolation of infectious bursal disease virus from turkeys with arthritic and respiratory symptoms in commercial farm in Quebec.Avian Dis. 35:3-7.

Rosales, A.G.; Villegas, P.; Lukert, P.D.; Fletcher, O.J. and Brown, J. (1989): Immunosuppressive potential and pathogenicity of a recent isolate of infectious bursal disease virus in commercial broiler chickens. Avian Dis. 33:724-728.

Rosenberger, J. K., Y. M. Saif, and D. J. Jackwood (2008):

Infectious Bursal Disease In: A laboratory manual for the isolation and identification of avian pathogens, 5th ed. L. DufourZavala, D. E. Swayne, J. R. Glisson,
J. E. Pearson, W. M. Reed, M. W. Jackwood, P. R. Woolcock, eds. American Association of Avian Pathologists. 188-190.

Silva, S.E.L.; Ferreira, H.L.; Carvalho, B.A. and Cardso, T.C. (2004): Susceptibility of mammalian cell line for isolation of IBDV from clinical samples $\mathrm{Br}$. J. Poult.Sci. 6: 65-69.

Tao, S.H.; Wei, L.; Sun, Y.T.; Qiao, Y.R. and Yao, W.G. (1995): Preliminary study of infectious bursal disease virus adapted to vero cell line Chinese.J. Vet. Med. 21: 35.

Tsai, H.J. and Saif, Y.M. (1992): Effect of cell culture passage on the pathogenicity and immunogenecity of infectious bursal disese virus Avian Dis. 36: 415-422.

Van den Berg, T. P., N. Eterradossi,D. Toquin and G. Meulemans (2000): Infectious bursal disease (Gumboro disease) .Rev SciTech 19:509-43.

Yamaguchi, T., M. Ogawa, Y. Inoshima, M. Miyoshi, H. Fukushiand K. Hirai (1996): Identification of sequence changes responsible for the attenuation of highly virulent infectious bursal diseasevirus .Virology 223:219-23. 


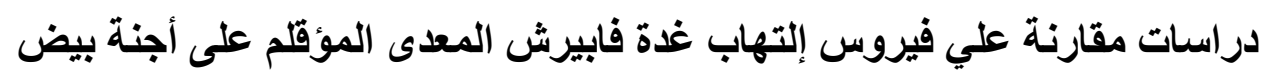

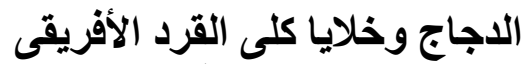

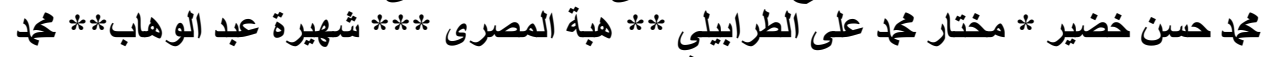

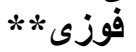

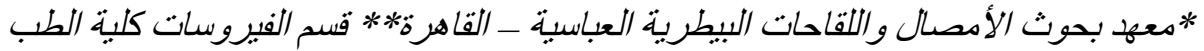

البيطري جامعة قناة السوبيس***طبيية بيطرية حرة

البحث ييين مدى تأثثير أقلمة فيروس إلتهاب غدة فابريش المؤقلم على المز ارع النسيجية على طبيعته

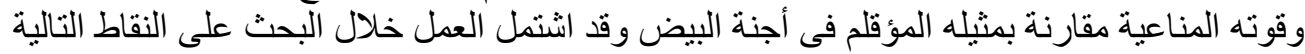

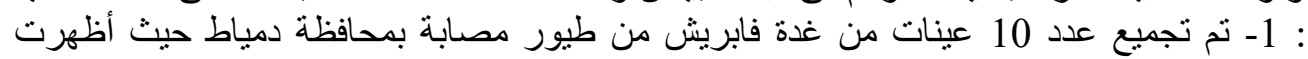

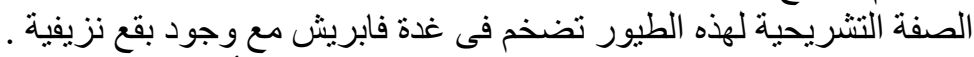

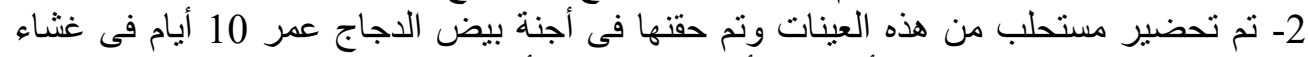

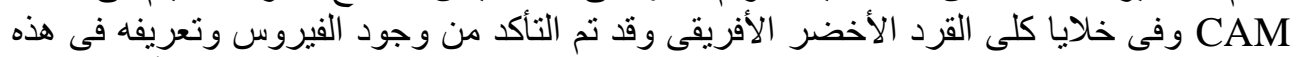

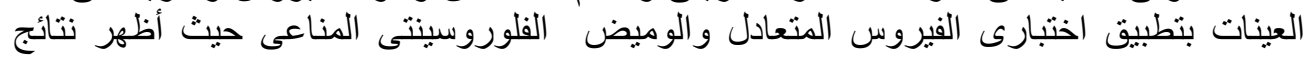

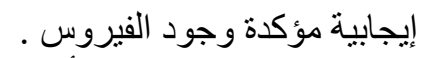

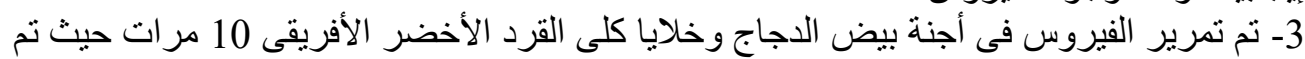

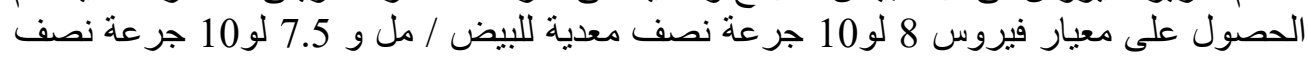

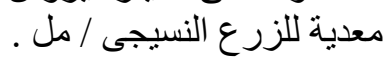

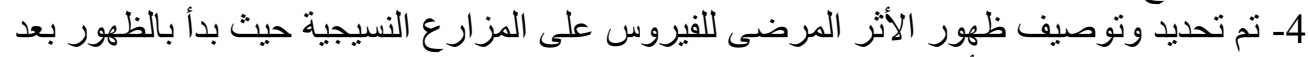

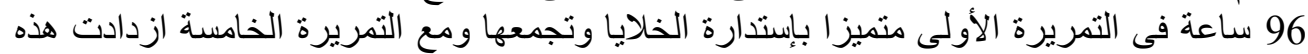

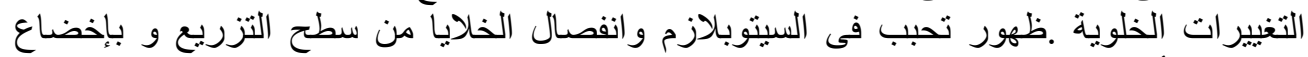

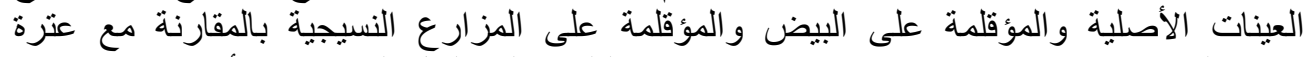

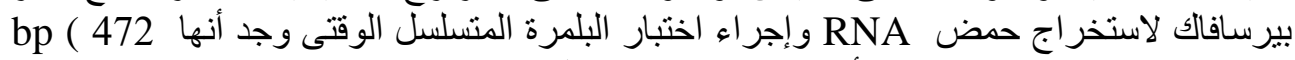

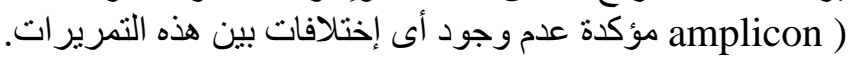

